\title{
Pengembangan Bahan Ajar Puzzle pada Matematika Berbasis Realistik Materi KPK dan FPB (Studi pada Kelas 5 SDN Bendogerit 1 Kota Blitar)
}

\author{
Mohamad Fatih \\ Universitas Nadlatul Ulama Blitar, Indonesia \\ Email: fatih.azix@gmail.com
}

\section{Tersedia Online di \\ http://www.jurnal.unublitar.ac.id/ index.php/briliant}

\section{Sejarah Artikel}

Diterima pada 17 Agustus 2019

Disetujui pada 25 Mei 2020

Dipublikasikan pada 30 Mei 2020

Hal. 348-361

Kata Kunci:

Puzzle, Matematika Realistik; KPK dan FPB

\section{DOI:}

http://dx.doi.org/10.28926/briliant .v3i4.348

\begin{abstract}
Abstrak: Penelitian ini bertujuan untuk mengembangkan bahan pembelajaran untuk lebih memahami Least Common Multiple (LCM) dan Greatest Common Divisor (GCD) berdasarkan Pendidikan Matematika Realistis dengan bantuan puzzle untuk penggunaan yang valid, efektif dan praktis untuk siswa kelas 5 SDN Bendogerit 1 Kota Blitar. Model pengembangan dalam penelitian ini menggunakan model 4D, tetapi meniadakan fase diseminasi. Validitas produk dinilai oleh tiga validator yaitu ahli materi, media, dan bahasa. Sementara kepraktisan dan efektivitasnya dinilai oleh dua pengamat dan siswa pengguna selama pengujian lapangan. Instrumen penelitian terdiri dari (1) angket validasi, (2) lembar observasi, (3) panduan wawancara, dan (4) tes. Hasil dari proses validasi dari ketiga validator menunjukkan bahwa media pembelajaran telah memenuhi kriteria "valid". Pengujian lapangan menghasilkan label "praktis" dan "efektif" dari penggunaan bahan ajar puzzle materi KPK dan FPB.
\end{abstract}

\section{PENDAHULUAN}

Pada kenyataanya pembelajaran matematika cenderung pada tingkat menghafal dari pada pemahaman dan penerapan konsep matematika. Selain itu, pemecahahan persoalan matematika masih dianggap sulit dan menjadi menjadi beban tersendiri bagi siswa. Hal tersebut menjadikan pelajaran matematika tidak disenangi siswa (Asra. 2004).

Disisi lain, guru menggunakan metode dan model pembelajaran konvensional diantaranya ceramah. Hal tersebut membuat siswa merasa bosan dan tidak konsentrasi serta mengurangi minat belajar siswa. Hal itu terbukti dengan prestasi belajar siswa di masih di bawah rata-rata, khususnya pada pembelajaran matematika.

Saat mengajar matematika, guru hendaknya perlu mengetahui karakteristik pembelajaran matematika. Karakteristik tersebut antara lain, bersifat abstrak. Sifat abstrak tersebut dikarenakan simbol yang digunakan dalam pembelajaran matematika anggka, garis dan lainya (Adam, D, \& Hamm, M. 2010). Karakteristik berikutnya pembelajaran matematika memerlukan logika dan daya nalar yang tinggi. Berdasarkan hal tersebut pembelajaran matematika hendaklah disusun secara herarki dari yang sederhana ke sedang dan kemudian ke tingkat yang sulit. 
Pada kehidupan nyata, tidak banyak ditemukan penggunaan konsep matematika. Hal tersebut senada dengan pendapat Flegg (dalam Wijaya 2012:6) kebutuhan manusia sebenarnya masih membutuhkan konsep matematika namum sangat jarang diaplikasikan pada kehidupan nyata.

Oleh sebab itu, pedekatan dan model pembelajaran realistik merupakan alrternatif untuk mengatasi implementasi konsep pembelajaran matematik ke dalam kehidupan nyata. Freudenthal dalam (Wijaya, 2012:13) menyatakan pendekatan pembelajaran realistik matematik menekankan pada kebermaknaan. Kebermaknaan tersebut mengaitkan konsep pembelajaran matematikan dengan meyesuaikan pengetahuan dan pengalaman siswa dalam kehidupan sehari-hari. Hal tersebut senada dengan Adan dan Hamm (dalam Wijaya, 2012:5) yang menyatakan konsep matematika dan pengalaman siswa dalam kehidupan nyata saling terkait.

Menurut Hudoyo (1990:79) mengemukakan bahwa pembelajaran matematika saat ini memerlukan perbaikan sebagai penyempurnaan matematika. Hal tersebut disebabkan masih banyak permasalahan yang muncul berkaitan dengan pembelajaran matematika diantaranya kurikulum, model pembelajaran, kualitas guru, serta pengunaan sumber belajar oleh siswa dan guru pada pembelajaran (Asra, 2004).

Hasil Observasi awal yang dilakukan pada siswa Sekolah Dasar Negeri Bendogerit 1 Kota Blitar terutama kelas 5 tanggal 10 September 2018, menunjukkan bahwa pembelajaran matematika materi Klipatan Persekutuan Terkecil (KPK) dan Faktor Kelipatan Persekutuan Terbesar (FPB) dilaksanakan dengan mengunakan metode ceramah tanpa bahan ajar dan media pembelajaran. Selain itu pembelajaran yang dilaksanakan tidak mengunakan bahan ajar yang sesuai justru mengunakan lembar kerja siswa yang bersifat tekstual. Setelah di investigasi lebih dalam bahan ajar lembar kerja siswa yang digunakan tidak menyajikan masalah kontekstual berupa ilustrasi atau konsep kehidupa nyata melainkan soal yang bersifat hafalan dan bukan masalah yang nyata dialami siswa dalam keseharian.

Berdasarkan hasil wawancara dengan guru kelas 5 Sekolah Dasar Negeri Bendogerit 1 Kota Blitar yang disertai dengan data daftar nilai siswa, diketahui bahwa 25 siswa dari keseluruhan 32 siswa (78\%) siswa Kelas 5 mengalami kesulitan dalam menyelesaikan KPK dan FPB. Data yang diperoleh menunjukkan nilai formatif pada materi KPK dan FPB yang belum memenuhi harapan, yaitu 78\% siswa mendapatkan rata-rata nilai dibawah 70 . Berarti mengindikasikan kriteria minimum belum terpenuhi.

Berdasarkan pemaparan tersebut, dapat dinyatakan bahwa siswa mengalami kesulitan dalam mempelajari KPK dan FPB. Hal tersebut disebabkan (1) siswa kurang memahami materi bahan ajar, dan berdampak sulit mengulang kembali konsep yang diajarkan, (2) pembelajaran bersifat konvensional, (3) aplikasi bentuk soal yang diberikan guru tidak kontekstual, (4) belum adanya bahan ajar yang memfasilitasi siswa untuk belajar aktif dan mengkonstruksi pengetahuan sendiri dalam pembelajaran matematika, dan (5) belum ada media yang konkret untuk membantu siswa memahami materi KPK dan FPB.

Pada pengembangan bahan pembelajaran, Fadjar (2010) mengungkapkan bahwa proses pembelajaran yang mengunakan bahan pembelajaran dapat memberikan kontribusi kegiatan pembelajaran yang bermutu. Implementasi bahan pembelajaran dapat menjadikan pembelajaran lebih tersusun dan terencana secara 
sistematis dengan mandiri, jelas, tuntas dan hasil yang baik (BNSP, 2006). Pembelajaran dengan bantuan puzle telah terbukti meningkatkan mutu atau kualitas proses dan hasil belajar. Nugroho (2008) menurut penelitiannya mengungkapkan bahwa pembelajaran dengan bahan ajar memberikan konstribusi yang signifikan terhadap peningkatan dan perolehan hasil belajar siswa.

Selain bahan ajar yang perlu diperhatikan lagi adalah adanya media. Media pembelajaran merupakan seperangkat alat bantu yang digunakan untuk mengantarkan pesan dari penyampai pesan ke penerima pesan dalam hal ini guru dan siswa. Hal tersebut dapat mempermudah anak memahami suatu materi, dan menurunkan tingkat keabstrakan suatu materi. Media yang tepat untuk pengembangan bahan ajar berbasis matematika realistik ini adalah media kongkret. Media kongkret mempermudah belajar mandiri siswa dan dapat mengkontruksi pengetahuan konsep matematika secara baik dan benar.

Lebih lanjut, Patmono dewo (dalam Misbach, 2010) mengungkapkan kata puzzle merupakan kata bentukan dari Bahasa Ingris yang mempunyai arti tekateki atau bongkar pasang. Penggunaan puzzle dimainkan dengan bongkar pasang. Berdasarkan hal tersebut, media puzzle merupakan permainan edukatif yang dapat merangsang keaktifan dan kemampuan berfikir logik dengan cara membongkar kepingan antar pasangan puzzle.

Hasil observasi menunjukan bahwapendekatan pembelajaran matematika yang selama ini digunakan belum optimal. Hal demikian membutuhkan suatu pendekan pada pembelajaran matematika untuk meningkatkan pemahaman siswa terhadap materi KPK dan FPB. Pendekatan yang memungkinkan siswa berani mengemukakan pendapat, siswa belajar matematika dengan penalaran, matematika yang dikemas secara kontekstual, siswa aktif dalam kegiatan pembelajaran, penyajian materi sesuai dengan perkembangan kognitif siswa, atmosfer interaksi siswa dengan siswa, siswa dengan guru dan materi secara berkelanjutan.

Matematika realistik salah satu alternatif pembelajaran matematika kontekstual yang diharapkan. Konsep pendidikan matemetik reaslistik digunakan pada pembelajaran matematika akan menguatkan sebagai fondasi pemahaman siswa (Wijaya, 2012:21). Pembelajaran matemtaik realistik membangun pemahaman dengan analisa teori, definisi, sifat, karakter suatu konsep secara mandiri. Hal tersebut berlawanan dengan konsep pembelajaran konvensional yang menerapkan pemahaman konsep melalui definisi, teorima dan sifat serta contoh yang diajarkan oleh penyampai pesan guru, kepada penerima pesan siswa. (Hobri, 2008:34)

Matematik realistik menitikberatkan pada masalah kontekstual. Pembelajaran tidak lagi bersifat guru sebagai pusat pembelajaran melainkan berpusat kepada siswa. Guru bertindak sebagai fasilitator sedangkan siswa aktif mengkomunikasikan ide-ide yang dimiliki. Siswa mengambil keputusan mereka sendiri tentang ide dan gagasan mereka sementara guru hanya mengkoordinasikan ide-ide siswa tersebut. Treffers (dalam Wijaya, 2012) mengemukakan pendidikan matematika realistik mempunyai inti antara lain, (1) penemuan permasalahan kontekstual, (2) memberikan solusi atas permasalan, (3) mengkoordinasi permasalahan tersebut.

Merancang pembelajaran matematika realistik, Gravemeijer (dalam Siswoyo, 2011) menyatakan ada tiga prinsip utama yang harus diperhatikan (1) matematika progresif melalui penemuan terbimbing, (2) fenomena didaktis, (3)

350 BRILIANT: Jurnal Riset dan Konseptual

Volume 5 Nomor 2, Mei 2020 
pengembangan diri. Prisip tersebut didukung dan dikuatkan oleh Trefers dalam (Wijaya: 2012:13) yang mengungkapkan (1) kontek, (2) model, (3) Pemenfaatan konstruksi siswa, (4) interaksi, (5) Keterkaitan.

Menurut Siswoyo (2011) langkah-langkah pembelajaran matematika berbasis PMR antara lain (1) pemahaman masalah yang bersifat kontekstual, (2)mendeskripsikan masalah kontekstual, (3) membandingkan ide dan gagasan, serta (4) memeberikan kesimpulan.

Berdasarkan prinsip dan karakteristik matematik realistik, maka bahan ajar mempunyai karakteristik antara lain (a) topik-topik yang akan diajarkan, permasalahan di dalam modul diupayakan berasal dari fenomena / kehidupan sehari-hari siswa (realistic problem), (b) setiap siswa diberi kesempatan yang sama untuk menyelesaikan masalah realistik yang mempunyai berbagai kemungkinan penyelesaian, (c) pengorganisasian siswa di dalam modul teks memungkinkan siswa berinteraksi dengan teman sesama, berdiskusi dan membandingkan jawaban, dan (d) kesimpulan oleh siswa dari topik yang dipelajari berdasarkan hasil diskusi kelompok.

Pada pembelajaran materi KPK dan FPB dengan pembelajaran berbasis PMR, pembelajaran dimulai dengan solusi masalah yang berhubungan dengan kontektual siswa atau sesuai masalah yang ada dalam pikiran mereka. Proses pemecahan masalah yang diberikan memerlukan aktivitas berupa bahan ajar puzzle. Selain itu, aktivitas mental yang tinggi juga diperlukan untuk mendalami dan memehami konsep. Hal demikian, untuk memahami konsep KPK dan FPB, siswa dilibatkan aktif.

Penelitian yang sesuai dengan peneltian ini dilakukan oleh kadarwati (2004) yang berjudul "Pendekatan Realistik Matematika pada Pembelajaran Perkalian dan Pembagian Bilangan Cacah bagi Siswa Kelas II SDN Sidorejo Kota Salatiga". Hasil penelitian ini diketahui bahwa melalui pembelajaran realistik dapat meningkatkan pemahaman konsep pembagian dan perkalian kedalam kehidupan nyata.

Penelitian selanjutnya dilakukan oleh Royani (2008) dengan judul "Pendekatan Realistik dalam Soal Cerita pada Buku Matematika Sekolah Dasar" yang menghasilkan penemuan bahwa soal-soal cerita yang realistik lebih banyak untuk membantu pemahaman siswa". Hasil penelitian membuktikan secara empiris tentang prospek pengembangan dan implementasi matematik realistiki pada pembelajaran saat ini. Berdasarkan analisis penelitian yang aka dilakuka dengan penelitian sebelumnya terdapat pada jenis penelitian dan variable penelitian. Penelitian yang akan dikembangkan matemtaik realistik merupakan pendekan yang digunakan dengan bahan ajar puzzle, sementara penelitian terdahulu menerapkan pendekatan matematik realistic pada pembelajaran di sekolah.

Tujuan penelitian yang akan dilakukan mengembangkan bahan ajar puzzle materi KPK (kelipatan persekutuan terkecil) dan FPB (kelipatan persekutuan terbesar) melalui pendekatan pendidikan matematika realistik pada siswa kelas 5 Sekolah Dasar Negeri Bendogerit 1 Kota Blitar secara valid, praktis dan efektif.

Spesifikasi secara teknis, (1) penulisan bahan ajar ditulis dengan bahasa yang Komunikatif, jelas dan lugas untuk mendukung penyajian materi yang mudah dipahami, (2) bahan ajar berbentuk modul dengan mengikuti format modul, (3) warna, gambar dan ilustrasi bahan ajar sesuai dengan karakteristik siswa Sekolah Dasar, dan (4) penulisan dan ukuran huruf bahan ajar mudah dibaca. 
Sedangkan spesifikasi secara substansi (1) materi KPK dan FPB dalam bahan ajar disajikan dengan urutan yang sistematis supaya mudah dipahami, yakni dengan cara materi diorganisasikan isinya sesuai dengan tingkat kompleksitasnya masing-masing yang didasarkan pada hasil analisis pembelajaran, (2) bahan ajar menyajikan suatu masalah dalam kehidupan nyata disertai contoh-contoh, (3) bahan ajar yang akan dikembangkan memuat komponen-komponen antara lain peta kompetansi dan peta konsep, tujuan pembelajaran, uraian materi, rangkuman, latihan, umpan balik, dan tindak lanjut. Spesifikasi produk puzzle antara lain (1) puzzle terbuat dari kertas karton yang berupa puzzle bongkar pasang yang terdiri dari simbol bilangan, (2) puzzle terdiri dari bilangan-bilangan dengan font yang sesuai dengan tingkat karakter siswa SD.

Keterbatasan pengembangan bahan pembelajaran / ajar Puzle yaitu (1) pengembangan bahan ajar pada tahap uji kelayakan, (2) bahan ajar yang dihasilkan terbatas pada bahan ajar puzzle (3) materi yang disajikan dalam bahan ajar hanya terbatas materi kelipatan persekutuan terkecil (KPK) dan kelipatan persekutuan terbesar (FPB) untuk siswa kelas 5 Semester 1 SDN Bendogerit 1 Kota Blitar, dan (4) pada kelayakan, bahan ajar puzzle diujikan pada kelompok kecil.

\section{METODE}

\section{Model Pengembangan}

Pengunaan model pengembangan pada penelitian ini mengunakan model 4D yang telah dikembangkan oleh Thiagarajan dan Samuael (dalam Hobri, 2010:28). Modifikasi model 4D dan pertimbangan pengunaan model ini didasarkan pada prosedur yang sesuai dengan langkah yang sistematis. Selain itu alasan mendasar yang lain terprogramnya sistem model yang sistematis menyesuaikan sumber dan bahan belajar yang sesuai dengan karkteristek siswa kelas 5 SD. Pertimbangan berikutnya model ini tidak hanya menitikberatkan rancangan tetapi bagaimana pengembangan bahan ajar.

Ada beberapa tahapan pada model 4D diantaranya, (1) tahap difinisi (define), (2) rancangan (design), (3) pengembangan (develop), (4) penyebaran pengembangan (desiminate). Tahap pertama sampai ketiga yaitu pendefinisian, perancangan, dan pengembangan sering disebut sebagai bagian perancangan. Sedangkan tahap akhir merupakan tahap hasil pengembangan produk setelah direvisi sehingga perlu penyebarluasan pengembangan.

\section{Prosedur Pengembangan}

Prosedur pengembangan bahan ajar matematika dengan bahan ajar puzle berbasis matematik realistik mengunakan tahapan model 4D. Adapun modifikasi tahapan dilakukan karena keterbatasan waktu dan membutuhkan eksperimen lebih lanjut (Miswanto, 2012:32). Tahapan yang dilakukan antara lain, (1) pendefinisian (define), (2) perancangan (design), (3) pengembangan (develop). Sementara tahapa penyebaran (desiminate) tidak dilakuakan.

\section{Tahapan Pendefinisian (Define)}

Pada tahapan pendefinisian (define) yang dilakukan menetapkan dan mendefinisikan syarat pembelajaran. Tahap pendefinisian terdiri dari (1) analisis terdepan, (2) analisis siswa, pada peniltian ini siswa yang diteliti kelas 5. Siswa di analisis dari segi perkembangan kognitif, afektif dan psikomotor, (3) analisis 
konsep, pada penelitian ini konsep yang digunakan terkait KPK dan FPB matapelajaran matematika. (4) analisis tugas, tugas dalam hal ini terkait penyelesaian bongkar pasang puzzle, (5) spesifikasi indikator pembelajaran.

\section{Tahapan Perancangan (Design)}

Pada tahapan perancangan (design) yang dilakukan menyiapkan rancangan dasar berupa prototipe bahan ajar puzzle berbasis matematika realistik. Materi KPK dan FPB yang dikembangkan harus sesuai dengan kehidupan nyata siswa. Produk prototipe mengacu pada sintak pendekatan matematika realistik. Pada tahap perancanhan ini meliputi 3 bagaian diantaranya (1) rancangan pendahuluan, (2) rancangan inti / pembelajaran (3) rancangan akhir / evaluasi.

\section{Tahapan Pengembangan (Develop)}

Tahapan pengembangan ini merupakan tahapan tindak lajut dari tahapan rancangan yang terdiri dari rancangan pendahuluan, inti / pembelajaran dan akhir / evaluasi.

\section{Uji Coba Produk}

Tujuan uji coba produk untuk mendapatkan kevalidan data sebagai bahan kajian revisi / perbaikan untuk ketercapaian keefektidan dan kepraktisan pruduk bahan ajar puzzle ini. Validasi ahli dan praktisi dilakukan sebelum uji coba lapangan,yang digunakan untuk megukur tingkat kevalidanya. Pelaksanaan uji coba dilakukan pada siswa kelas 5 SDN Bendogerit 1 Kota Blitar. Hasil uji coba lapangan berikutnya dilakukan analisa dan kemudian direvisi untuk mendapatkan produk bahan ajar dengan media puzzle berbasis matematik realistik pada materi KPK dan FPB yang valid, praftis dan efisien.

Uji coba lapangan dilakukan dengan skala terbatas pada produk pengembangan bahan ajar matematika dengan bahan ajar puzzle pada materi KPK dan FPB berbasis matematik realistik siswa kelas 5 SDN Bendogerit 1 Kota Blitar. Data uji coba berdasarkan kriteria produk yang diperoleh dari penelitian dan tanggapan dari para ahli.

Aspek kevalidan dan bahan ajar dan media ini dikaitkan tiga hal, yaitu (1) kevalidan dari aspek isi, (2) kevalidan dari aspek desain, dan (3) kevalidan dari aspek bahasa. Kevalidan ini dapat diketahui melalui validator ahli materi, design dan bahasa.

Aspek berikutnya keefektidan dan kepraktisan bahan ajar yang beriktan dengan pengunaan bahan ajar puzzle dapat mempermudah pemahaman materi dan menarik untuk digunakan bagi siswa. Keefiktifan dan kepraktisan ini dapat diketahui melaui hasil belajar siswa, aktivitas siswa dan guru pada pembelajaran dan respon siswa terhadap bahan ajar puzzle.

Pada pelaksanaan uji coba pengembangan mengunakan subjek para ahli yang telah memenuhi kriteria dalam pengembangan media pembelajaran dan menguasai materi yang dikembangkan. Pada hal ini peneliti mengambil 3 ahli sebagai ahli isi atau materi, hali media dan ahli bahasa, yaitu dosen yang mempunyai ahli ilmu matematika, dosen berkualifikasi teknologi pembelajaran dan dosen ahli bahasa.

Sebagai subjek dalam coba produk pada kelompok terbatas atau kecil serta pelaksanaan uji coba lapangan untuk mengukur tingkat kelayakan bahan ajar yang 
dikembangkan yaitu berbasis matematik realistik berbantuan puzzle pada materi KPK dan FPB. Penelitian ini dilakukan pada semester ganjil Tahun Pelajaran 20182019 pada siswa Kelas 5 SDN Bendogerit 1 Kota Blitar.

Pada pelaksanaan uji coba pengemabngan bahan ajar puzzle materi KPK dan FPB berbasis matematik realistik mempunya 2 jenis data yaitu data kualitatif dan kuantitatif. Data kualitatif memuat tangapan, respon, komentar, saran, masukan perbaikan dari validator dan observer. Valitaor tersebur mencakup validator isi, design, dan Bahasa. Sementara observer mencakup pengamatan aktivitas siswa, guru dan keterlaksanaan bahan ajar pada siswa kelas 5 SDN Bendogerit 1 Kota Blitar. Hasil tanggapan, komentar, saran masukan perbaikan tersebut akan digunakan revisi bahan ajar puzzle.

Sedangkan hasil data kuantitatif diperoleh dari validator ahli, media / design, Bahasa, observer, wawancara respon siswa, berupa skor. Kemudian dianalisa dan diolah disesuaiakan dengan kriteria yang sidah ditetapkan, sehingga dapat disimpulkan tingkat kevalidan dan kelayakan bahan ajar puzzle tersebut.

Pengunaan instrument berupa (1) angket, (2) lembar observasi, (3) pedoman wawancara dan (d) hasil belajar untuk mengukur tingkat kevalidan, keefektifan dan kepraktisan. Instrument angket diberikan ke validator materi, design dan Bahasa. Sedangkan lembar observasi digunakan pada pembelajaran berlangsung khususnya pada pegunaan bahan ajar puzzle. Sementara instrument pedoman wawancara digunakan kepada guru. Hasil instrumen tersebut dianalisa dengan teknik analisa data yang telah ditentukan.

Lembar observasi yang dimaksud terdiri dari (1) lembar observasi aktivitas siswa digunakan sebagai pedoman untuk mengamati kepraktisan bahan ajar matematika yang dikembangkan dan untuk memperolah gambaran tentang aktivitas siswa dalam menggunakan bahan ajar matematika selama proses uji coba produk berlangsung, (2) pengunaan gambaran tentang aktivitas guru dalam mengunakan bahan ajar matematika berbantuan puzzle selama proses uji coba lapangan dengan lembar observasi aktivitas (3) lembar observasi keterlaksanaan bahan ajar digunakan sebagai dasar untuk melihat kepraktisan melalui keterlaksanaan bahan ajar puzzle materi KPK dan FPB berbasis matematik realistik.

Instrumen hasil belajar dugunakan untuk mengukur tingkat keefektifan bahan ajar puzzle yang dihasilkan. Tes hasil belajar terdiri dari tes latihan, tindak lanjut, dan hasil evaluasi. Perhitungan dari keseluruhan hasil belajar adalah 30\% dari tes latihan, $20 \%$ dari tindak lanjut, dan 50\% dari hasil evaluasi. Data akan dianalisis dan hasilnya akan disesuaikan dengan kategori tingkat keefektifan yang telah ditentukan. Hasil belajar juga menentukan ketuntasan siswa. Jika diperoleh kesimpulan bahwa tes hasil belajar ini belum mencapai $80 \%$ nilai kriteria ketuntasan minimum (KKM) yaitu 70. Hal tersebut mengindikasikan siswa belum menguasai materi.

Instrumen pedoman wawancara digunakan untuk mengetahui respon siswa terhadap bahan ajar puzzle materi KPK dan FPB berbasis matematik realistik. Pedoman wawancara digunakan untuk mengumpulkan data berupa respon siswa positif atau negatif dari subjek uji coba untuk memperbaiki kekurangan yang ada dalam produk bahan ajar hasil pengembangan.

Pada teknik analisa data pada penelitian ini berupa (1) catatan saran, masukan dan komentar pada lembar validasi oleh ahli materi, design, bahasa dan

354 BRILIANT: Jurnal Riset dan Konseptual Volume 5 Nomor 2, Mei 2020 
lembar observasi. (2) skor dari hasil validasi ahli dan observasi, respon siswa, serta ketuntasan belajar menggunakan analisis statistik deskriptif.

\section{HASIL}

\section{Tahap Definisi (Define)}

Pada ini merupakan tahap awal pengembangan. tahap definisi meliputi sebagai berikut, (1) analisis penentuan pokok permesalahan atau temuan yang diperlukan untuk perangkat pembelajaran yang akan dikembangkan di SDN Bendogerit 1 Kota Blitar dengan cara melakukan diskusi dengan guru matematika, (2) analisis siswa dengan menganalisis karakteristik siswa Kelas 5 SDN Bendogerit 1 Kota Blitar Tahun Pelajaran 2018-2019, meliputi latar belakang kemampuan akademik untuk mata pelajaran prasyarat yaitu kelipatan dan faktor, (3) analisis konsep dengan mengidentifikasi konsep KPK dan FPB yang diimplementasikan pada pembelajaran yang disusun secara sistematis, membuat peta konsep yang mengaitkan materi satu dengan yang lainya, (4) analisis tugas dengan melakukan identifikasi berbagai keterampilan yang disesuaikan dengan pencapaian indikator pembelajaran, dan (5) spesifikasi indikator pembelajaran didasarkan pada Kompetensi Dasar (KD) dan indikator pada silabus matematika Kelas 5 Semester 1.

\section{Tahap Perancangan (Design)}

Pada perancangan bahan ajar puzzle berbasis matematik realistik akan menghasilkan perancangan berupa draf-1. Adapun kegiatan yang dilakukan pada tahapan ini antara lain (1) rancangan pendahuluan yang terdiri dari deskripsi, prasyarat, petunjuk penggunaan, tujuan, kompetensi, cek kemampuan dan peta konsep, (2) rancangan pembelajaran, yang terdiri dari kegiatan penentuan FPB dan KPK dari 2 bilangan, penyelesaian masalah FPB dan KPK, umpan balik, dan tindak tindak lanjut, serta (3) rancangan evaluasi yang berbentuk essay yang berkaitan FPB dan KPK masalah realistik

\section{Tahap Pengembangan (Develop)}

Pada tahap pengemabangan dari rancangan yang sudah dibuat pada tahap sebelumnya atau perancangan terdiri meliputi 3 bagian antara lain, pendahuluan , (2) pembelajaran, dan (3) evaluasi.

\section{Hasil Validasi}

Perolehan skor rata-rata pada keseluruhan aspek (Va) sebesar 3,31 hasil validasi ahli materi terhadap bahan ajar puzzle yang dikembangkan. Berdasarkan kriteria kevalidan yang telah ditetapkan maka prototipe yang telah dikembangkan memperoleh nilai kevalidan sangat baik. Sementara komentar dan saran ahli materi digunakan untuk perbaikan pemaparan konsep yang kurang jelas bagi siswa.

Tabel 1. Kriteria Kevalidan

\begin{tabular}{lccl}
\hline No & Rentang Nilai & Klasifikasi & Kesimpulan \\
\hline 1 & $1,00 \leq \mathrm{Va} \leq 1,75$ & Tidak Baik & Perangkat masih memerlukan konsultasi Intensif \\
\hline 2 & $1,76 \leq \mathrm{Va} \leq 2,50$ & Kurang Baik & Perangkat dapat digunakan dengan banyak revisi \\
\hline 3 & $2,56 \leq \mathrm{Va} \leq 3,25$ & Baik & Perangkat dapat digunakan dengan sedikit revisi \\
\hline 4 & $3,26 \leq \mathrm{Va} \leq 4,00$ & Sangat Baik & Perangkat dapat digunakan tanpa revisi \\
\hline \multicolumn{4}{c}{ Keterangan $=$ Va: tingkat kevalidan validator }
\end{tabular}


Berdasarkan hasil validasi ahli design tentang bahan ajar, mendapatkan skor keseluruhan aspek $\left(\overline{V_{a}}\right)$ adalah 3,51. Hal tersebut prototipe bahan ajar mendapat kriteria valid. Saran dan komentar berkaitan dengan penataan kembali desain sampul bahan ajar karena terkesan ramai dan perlu diperhatikan lagi keseimbangan judul, logo dan lain-lain. Saran lain perlu dikaji ulang tahapan kerja dalam penggunaan bahan ajar perlu dicoba pada siswa sebelum diuji lapangan.

Berdasarkan hasil validasi ahli bahasa bahan ajar, mendapatkan skor seluruh aspek $\left(\bar{V}_{a}\right)$ yaitu 3,47 . Hal tersebut mengindikasikan bahasa dalam bahan ajar dapat dikatakan valid. Saran dan komentar berkaitan dengan (1) pendahuluan hendaknya menggambarkan isi keseluruhan modul, membuat standar kompetensi, kompetensi dasar, dan tujuan instruksional, serta menjelaskan strategi mempelajari modul, (2) peta konsep sepertinya perlu ditukar posisi antara faktor bilangan (sebelah kanan) dan kelipatan persekutuan terkecil (sebelah kiri), (3) daftar isi perlu disesuaian dengan penomoran, dan (4) heading perlu ditata secara konsisten.

Berdasarkan hasil validasi ahli terhadap bahan ajar puzzle, skor yang diperoleh keseluruhan aspek $\left(\overline{V_{a}}\right)$ adalah 3,40. Hal tersebut mempunyai arti prototipe bahan ajar puzzle mendapat kriteria valid. Saran dan komentar berkaitan dengan perlu adanya penanda dari tiga puzzle yang ada serta petunjuk penggunaan puzzle untuk menyelesaikan masalah matematika perlu dicermati kembali.

\section{Uji Coba dan Analisis Data}

Uji coba lapangan dilakukan untuk memberikan penilaian kevalidan, keefektifan dan kepraktisan bahan ajar puzzle. Uji coba lapangan dilakukan pada siswa kelas 5 SDN Bendogerit 1 Kota Blitar. Uji coba dilaksanakan sebanyak 4 kali pertemuan. Uji coba lapangan dimulai pada tanggal 7 November 2018 sampai 30 November 2018.

Uji coba ini dilakukan terhadap siswa Kelas 5 SDN Bendogerit 1 Kota Blitar. Uji coba dilakukan sebanyak empat kali pertemuan. Uji coba berlangsung mulai tanggal 07 November 2018 sampai 30 November 2019. Kelas yang dipilih untuk subjek penelitian kelas 5 SDN Bendogerit 1 Kota Blitar. Jumlah siswa pada kelas 5 ini 32 siswa. Tiap pertemuan berdurasi 70 menit.

Uji coba observasi dilakukan oleh dua observer. Observer tersebut melaksanakan pengamatan keterlaksanaan bahan ajar puzzle, aktivitas guru dan siswa pada saat pembelajaran. Observer tersebut merupakan seorang guru Kelas 5 SDN Bendogerit 1 Kota Blitar.

Berdasarkan observasi dari dua observer diperoleh skor keseluruhan aspek keterlaksanaan bahan ajar puzzle pada setiap pertemuan satu, dua, tiga dan empat secara berurutan yaitu 3,$68 ; 3,78 ; 3,83$ dan 3,88. Hal tersebut berarti kepraktisan pada keterlaksanaan bahan ajar puzzle masing-masing pertemuan memenuhi klasifikasi tinggi.Pada aspek keterlaksanaan memperoleh rata-rata skor seluruh pertemuan yaitu 3, 75. Berdasarkan keterlaksanaan bahan ajar puzzle mempunyai kriteria tinggi. Hal ini kriteria kepraktisan bahan ajar yang telah ditetapkan terpenuhi.

Tabel 2. Kriteria Kepraktisan

\begin{tabular}{lccc}
\hline No & Rentang Nilai & Klasifikasi & Keterangan \\
\hline 1 & $0,00 \leq \beta \leq 1,00$ & Sangat Rendah & \\
\hline 2 & $1,01 \leq \beta \leq 2,00$ & Kurang & \\
\hline 3 & $2,01 \leq \beta \leq 3,00$ & Cukup & \\
\hline
\end{tabular}




\begin{tabular}{llc}
\hline 4 & $3,01 \leq \beta \leq 4,00$ & Tinggi \\
\hline & $4,01 \leq \beta$ & Sangat Tingg \\
\hline
\end{tabular}

Uji coba kemampuan diikuti oleh seluruh siswa Kelas 5 SDN Bendogerit 1 Kota Blitar sejumlah 32 siswa. Hasil latihan ditentukan dengan mengambil rata-rata dari dua hasil latihan dari empat pertemuan. Berdasarkan hasil belajar, sebanyak 27 siswa atau $84 \%$ dari 32 siswa memperoleh nilai di atas skor minimal 64, sedangkan 5 siswa atau 16\% memperoleh sekor kurang dari 64. Berdasarkan kriteria ketuntasan yang ada di SDN Bendogerit 1 Kota Blitar, maka prestasi hasil belajar siswa kelas 5 pada materi FPB dan KPK telah mencapai kriteria ketuntasan.

Berdasarkan hasil observasi aktivitas siswa dari 2 observer mendapatkan skor rata-rata aspek aktifitas siswa seluruh pertemuan yaitu 4,35. Hal ini mempunyai arti aktivitas siswa selama 4 pertemuan memnuhi kriteria sangat aktif. Berdasarkan hasil observasi aktivitas guru dari dua observer rata-rata skor seluruh aspek aktivitas guru pada seluruh pertemuan yaitu 3,79. Hal ini mempunyai arti aktivitas guru selama 4 pertemuan memenuhi kriteria aktif.

Tabel 3. Kriteria Keaktifan

\begin{tabular}{lccc}
\hline No & Rentang Nilai & Klasifikasi & Keterangan \\
\hline 1 & $0,00 \leq \mathrm{a} \leq 1,00$ & Tidak Aktif & \\
\hline 2 & $1,01 \leq \mathrm{a} \leq 2,00$ & Kurang Aktif & \\
\hline 3 & $2,01 \leq \mathrm{a} \leq 3,00$ & Cukup Aktif & \\
\hline 4 & $3,01 \leq \mathrm{a} \leq 4,00$ & Aktif & \\
\hline & $4,01 \leq \mathrm{a}$ & Sangat Aktif & \\
\hline
\end{tabular}

Berdasarkan hasil respon wawancara siswa pada bahan ajar puzle, adalah 95, dengan demikian memiliki kriteria respon sangat baik \& positif. Berdasarkan hasil wawancara respon siswa terhadap media puzzle, secara klasikal rata-rata respon siswa adalah 96, sehingga memenuhi respon sangat baik \& positif berdasarkan ketetapan kriteria.

Table 4. Kriteria nilai respon siswa

\begin{tabular}{lccc}
\hline No & Rentang Nilai & Klasifikasi & Keterangan \\
\hline 1 & $0,00 \leq \AA \leq 20,00$ & Tidak Baik & \\
\hline 2 & $21,01 \leq \AA \leq 40,00$ & Kurang Baik & \\
\hline 3 & $40,01 \leq \AA \leq 60,00$ & Cukup Baik & Baik \\
\hline 4 & $60,01 \leq \AA \leq 80,00$ & Sangat Baik & \\
\hline & $80,01 \leq \AA \leq 100,00$ & &
\end{tabular}

\section{Revisi Hasil Produk Pengembangan}

Menurut hasil analisa data kuantitatif, dapat dikethui bahwa pengembangan bahan ajar telah memenuhi kriteria valid, efekti, dan praktis, dengan demikian tidak memerlukan revisi. Pada data kualitatif aspek pengamatan memiliki saran, masukan, untuk perbaikan pengembangan

\section{PEMBAHASAN}

Berdasarkan pemaparan hasil penelitian pengembangan Bahan Ajar Puzzle Berbasis Matematika Realistik Materi FPB dab KPK diperoleh tingkat kevalidan sangat baik. Hal tersebut terbukti perolehan skor pada keseluruhan aspek (Va) sebesar 3,31 dari hasil validasi materi. Pengembangan bahan ajar puzzle berbasis matematika realistik materi FPB dan KPK sangat valid digunakan pada siswa kelas 5 SDN Bendogerit 1 Kota Blitar. 
Sementara hasil validasi ahli design tentang bahan ajar puzzle, mendapatkan skor keseluruhan aspek $\left(\overline{V_{a}}\right)$ adalah 3,51. Hal tersebut prototipe bahan ajar mendapat kriteria valid. Berdasarkan perolehan hasil skor dari ahli design bahan ajar puzzle sangat valid digunakan pada siswa kelas 5 SDN Bendogerit 1 Kota Blitar.

Hasil validasi berikutnya dari ahli bahasa. Diperoleh skor seluruh aspek sebesar 3,47. Hal tersebut mempunyai arti bahwa bahasa dalam bahan ajar puzzle valid. Sehingga bahasa dalam bahan ajar puzzle dapat digunakan pada kelas 5 SDN Bendogerit 1 Kota Blitar.

Pada tahap uji coba lapangan dapat diketahui tingkat kevalidan dan keefektifan serta kepraktisan produk bahan ajar puzzle berbasis matematik realistik. Hasil observasi skor keseluruhan aspek keefektifan dan kepraktisan bahan ajar puzzle berbasis matematika realistik berurutan 3,$68 ; 3,78 ; 3,83$ dan 3,88. Hal tersebut memenuhi kriteria keefektifan dan kepraktisan pada keterlaksanaan bahan ajar puzzle berbasis matematik realistik tinggi.

Pada uji coba perorangan dapat diketahui bagaimana keefektifan bahan ajar puzzle digunakan. Keefektifan dapat dilihat dari ketersampaian pesan dan pemahaman materi pada bahan ajar puzzle berbasis matematik realistik. Pada tahap uji coba perseorangan ini responden dipilih secara acak pada siswa berkemampuan tinggi, sedang, dan rendah. Siswa berkemampuan tinggi memberikan penilaian "sangat baik" pada 7 indikator. Kemudian 2 indikator penilaian "baik" dan penilaian "cukup" pada 1 indikator. Perolehan skor rata-rata siswa berkemampuan tinggi terhadap bahan ajar puzzle sebesar 4.0 sehingga dapat dikategorikan dalam kriteria "sangat efektif".

Keefektifan bahan ajar tersebut lebih terdapat pada tampilan dan cara penggunaan bahan ajar tersebut. Bahan ajar puzzle berbasis matematika realistik lebih mengedepankan tampilan visual dan bahan yang unik tetapi banyak disekitar kita. Selain itu, siswa merasa mempelajari materi FPB dan KPK diluar kebiasaan yang selalu diminta menghafal melainkan pratek langsung untuk membongkar pasang puzzle sesuai soal yang diberikan. Keefektifan tersebut terbukti nilai yang diperoleh siswa berkemampuan tinggi untuk menyelesaikan soal pada bahan ajar puzzle rata-rata 9,2.

Pada uji coba perorangan siswa berkemampuan sedang memberikan penilaian "sangat baik" untuk 5 indikator. Kemudian 3 indikator untuk penilaian "baik" dan 2 indikator untuk penilian "cukup". Perolehan skor rata-rata siswa berkemampuan sedang terhadap puzzle sebesar 3,9 sehingga dapat dikategorikan dalam kriteria "efektif".

Keefektifan bahan ajar puzzle berbasis matematik realistik terdapat pada pemahaman petunjuk penggunaan bahan tersebut. Siswa sangat terampil menggunakan bahan ajar puzzle berbasis matematik realistik meskipun penjelasan satu kali. Siswa merasa senang ketika mengunakan bahan ajar puzzle pada materi FPB dan KPK. Hal tersebut berdampak nilai perolehan penyelesaian soal materi FPB dan KPK mendapat nilai rata-rata 8,7.

Pada uji coba perorangan siswa berkemampuan rendah dapat diperoleh penilaian "sangat baik" untuk 4 indikator. Kemudian 4 indikator pada penilaian "baik" dan 2 indikator pada penilaian "cukup". Perolehan skor rata-rata siswa berkemampuan rendah sebesar 3,6 sehingga dapat dikategorikan dalam kriteria "efektif".

358 BRILIANT: Jurnal Riset dan Konseptual Volume 5 Nomor 2, Mei 2020 
Siswa berkemampuan rendah memberikan respon keefektifan bahan ajar puzzle berbasis matematik realistik terlebih pada jenis bahan ajar yang berbeda dan lebih mengedepankan pada permasalahan kontekstual dengan keseharian siswa. Teks yang ada pada bahan ajar puzzle tidak monoton dan tidak terlalu banyak. Mengingat minat baca siswa berkemampuan rendah sangat kurang maka bahan ajar puzzle berbasis matematika realistik ini sangat membantu untuk menyelesaikan soal materi FPB dan KPK.

Berdasarkan uji coba perseorangan terhadap bahan ajar puzzle secara keseluruhan mendapat penilaian "efektif". Oleh karena itu peneliti merasa tidak memerlukan revisi produk berupa bahan ajar berbasis matematik realistik. Penilaian efektif bahan ajar puzzle yang dikembangkan mendapat pesan dan kesan serta penilaian dari uji coba perseorangan pada kemudahan pemahaman materi dan pengunaan. Hal itu membawa perubahan nilai materi FPB dan KPK meningkat. Hal tersebut diperkuat dengan pendapat Wina Sanjaya (2010:224) menyatakan pertimbangan pemilihan dan pengunaan alat bantu, media, bahan pembelajaran akan mempengaruhi komunikasi secara intensif antara pemberi pesan dan penerima pesan yang berdampak pada pemahaman informasi.

Pada uji coba kelompok kecil dapat diketahui bahwa pengunaan bahan ajar puzzle berbasis matematik realistik mendapat nilai kepraktisan tinggi. Hal tersebut dibuktikan dengan perolehan skor rata-rata 3.75. Penilaian kepraktisan pada uji coba kelompok kecil ini mendapat skor tinggi pada indikator kemudahan pengunaan, ketepatan pemahaman, dan kecepatan penggunaan dan waktu pengunaan.

Penilaian tersebut menjadi dasar pertimbangan dalam langkah selanjutnya termasuk pada keputusan revisi. Pada keputusan peneliti tidak melakukan langkah revisi produk karena bahan ajar telah praktis untuk digunakan. Keterlaksanaan penggunaan bahan ajar puzzle mendapatkan kepraktisan sangat mendukung peningkatan penyampaian materi FPB dan KPK. Hal tersebut sesuai dengan pendapat Prastowo (2013) bahan ajar yang mudah digunakan dalam menyampaikan informasi pengetahuan dapat mempengaruhi pemahaman siswa. Dampak kepraktisan bahan ajar puzzle akan mempengaruhi peningkatan pemahaman dan prestasi siswa kelas 5 SDN Bendogerit 1 Kota Blitar.

\section{KESIMPULAN}

Karakteristik produk pengembangan ini merupakan bahan ajar berupa puzle yang memuat materi FPB dan KPK berbasis pembelajaran realistik. Ada pun rincian sebagai berikut Bab I pendahuluan yang memuat deskripsi, kemampuan prasyarat, petunjuk pengunaan, tujuan, kompetensi, cek kemampuan. Bab II pembelajaran meliputi beberapa kegiatan antara lain menentukan KPK, penyelesaian masalah terkait dengan materi KPK, menentukan FPB dan penentuan penyelesaian masalah yang terkait dengan FPB. Bab III evaluasi digunakan untuk mengetahui ketuntasan siswa untuk mempelajari tentang KPK dan FPB setelah menggunakan bahan ajar berbantuan puzzle, dan daftar pustaka memuat daftar rujukan sebagai sumber pustaka dalam menyusun bahan ajar.

Berdasarkan uji coba lapangan diperoleh catatan antara lain, ditemukan adanya kelebihan dari bahan ajar yang dikembangkan antara lain (1) bahan ajar yang mengunakan sumber belajar yang terkait dengan kehidupan nyata siswa. (2) bahan ajar disusun sesuai dengan karakteristik siswa Kelas 5 SDN Bendogerit 1 
Kota Blitar, (3) materi bahan ajar yang disajikan dalam pembelajaran untuk membimbing siswa membangun atau mengkontukssi konsep sendiri, (4) memberikan tempat bagi penguna untuk mengembangkan ide gagasanya, (5) bahan ajar mampu melatih siswa untuk menyelesaikan permasalahan realistik secara mandiri, (6) bahan ajar memberi peluang kepada siswa untuk berinteraksi dengan teman maupun guru.

Adapun sisi bahan ajar puzle yang harus diperhatikan sebagai keterbatasan, antara lain (1) analisa masalah karakteristik siswa dari tingkat kognitif, afektif dan psikomotor dan analisa pembelajaran materi KPK dan FPB pada siswa kelas 5 SDN Bendogerit 1 Kota Blitar. (2) alokasi waktu yang tidak sesuai dari perencanaan, waktu yang dialokasikan masih kurang, (3) permasalahan kehidupan nyata siswa berupa soal esai atau cerita yang disusun dalam bahan ajar merupakan hal yang belum biasa bagi siswa, sehingga ketika mereka membaca permasalahan tersebut, siswa masih banyak bertanya kepada guru, dan (4) kegiatan pada bahan ajar yang berfungsi untuk membantu siswa siswa menemutunjukan konsep pengetahuannya sendiri masih memerlukan bimbingan guru.

Menurut hasil validasi tiga validator dari ahli media/design, materi, bahasa, maka bahan ajar puzzle dapat dikembangkan secara valid, efektif dan praktis. Hal tersebut didukung pada tahapan uji coba perseorangan terhadap bahan ajar puzzle berbasis matematik realistik mendapat kriteria efektif. Dukungan berikutnya pada tahap uji coba kelompok kecil memperoleh kriteria penilaian praktis.

\section{SARAN}

Berdasarkan uji coba lapangan yang perludiperhatikan untuk mengoptimalkan pemanfaatan bahan ajar antara lain, (1) sebaiknya guru memanfaatan alokasi waktu dalam pengunaan bahan ajar yang telah disusun, (2) pembimbingan siswa oleh guru ketika menggunakan bahan ajar puzle berbasis PMR. Saran pada desiminasi yaitu (1) sebaiknya perlu dilakukan uji validasi pengembangan bahan ajar pada tahapan dari 3D ke 4D (2) sebiknya pengamatan awal terkait nanlisa karekteristik dan analisa pembelajaran materi KPK dan FBP pada siswa kelas 5 SDN Bendogerit 1 Kota Blitar dilakukan dengan cermat dan teliti.

Perlu diperhatikan saran pengembangan lebih lanjut antara lain (1) diperlukan analisis kebutuhan terlebih dahulu dari aspek siswa, materi, kurikulum, daln lainya, (2) berdasarkan temuan lapangan ketika melaksanakan studi pendahuluan, (3) berdasarkan pengalaman yang dimiliki peneliti terkait pembelajaran (4) pemilihan materi yang tepat dan sesuai untuk pengembangan bahan ajar Puzle berbasis Pendidikan Matematik Realistik. dan (5) studi leterasi dan penelitian terdahulu terkait pengembangan bahan ajar puzzle berbasis pendidikan matematik realisitik materi KPK dan FPB.

\section{DAFTAR RUJUKAN}

Adam, D dan Hamm, M. 2010. Demistify Math Science and Thecnology Creatitiy Innovation and Problem Solving. Plymouth: Rown and Litlefield Education.

Asra. 2004. Pengembangan Perangkat Pembelajaran Matematika Berdasarkan Pendekatan Konstruktivisme untuk Topik Persegipanjang dan Persegi di 
Kelas 1 SMP Negeri 22 Surabaya. Tesis yang tidak diterbitkan. Surabaya: Pascasarjana, Universitas Negeri Surabaya.

BNSP. 2006. Pengembangan Bahan Ajar. Jakarta: Kementerian Pendidikan Nasional.

Fadjar, S. 2010. Modul Matematika SMP Program Bermutu (Pembelajaran Matematika melalui Pendekatan Realistik di SMP). Yogyakarta: Jurnal UNY.

Flegg, G. 1983. Their History \& Meaning. New York: Schocken Book.

Freudenthal, H. 1991. Revisting Mathematic Education. Dordrecht: Kluwer Academic Publishers.

Hobri. 2008. "Realistic Mathematic Education (RME), Konsepsi dan Pelaksanaannya".Jember: Lembaga Penelitian Universitas Jember.

Hobri. 2010. Metodologi Penelitian Pengembangan, Aplikasi pada penelitian pendidikan matematika. Jember: Pena Salsabila.

Hudoyo, H. 1990. Strategi Dasar Mengajar Matematika. Malang: IKIP Malang.

Kadarwati. 2004. Pendekatan Realistik Matematika pada Pembelajaran Perkalian dan Pembagian Bilangan Cacah Siswa Kelas II SDN Sidorejo Kota Salatiga.Tesis yang tidak diterbitkan. Malang: PPS Universitas Negeri Malang.

Miswanto. 2012. Pengembangan Buku Siswa Bercirikan Penemuan Terbimbing Materi Eksponen. Tesis tidak diterbitkan. Malang: Pescasarjana Universitas Negeri Malang.

Nugroho, P. 2008. Pengembangan Modul Pembelajaran Menggunakan Teori Bruner Materi Kubus dan Balok. Tesis yang tidak diterbitkan. Malang: Pascasarjana Universitas Negeri Malang.

Prastowo. 2013. Pengembangan Bahan Ajar Tematik. Yogyakarta: Diva Press

Royani, M. 2008. Pendekatan Realistik pada Soal Cerita Buku Matematika SD. Jurnal Kependidikan dan Kemasyarakatan STIKIP PGRI Banjarmasin. Vol 3. No.1 Januari-Juni 2008.

Siswoyo, A. A. 2012. Pengemabngan Perangkat MAtematik Berbasis Realistic Mathematic Education (RME). Tesis yang tidak diterbitkan. Malang: Pascasarjana Universitas Negeri Malang.

Thiagarajan, S, Semmuel, D. S and Semmel, M.I. 1974. Instructional Develepment for Training Teacher of Exceptional Children. A Source Book Bloomington Center for Innovation on Teaching The Handicapped. Indiana: Indiana University.

Treffers, A. 1991. Didagtical Background of a Mathematic Program for Primary School. Dalam Leen Streefland (ED), Reaistic In Primary School: On The Occasion of The Opening of The Frendenthal Institute. Hlm 11. Netherland: Utrecht University, (CD- $\beta$ Press).

Van den Heuvel-Panhuizen, M. 1996. Assesment and Realistic Mathematics Education. Utrecht: SD-b Press, Center for Science and Mathematic Education.

Wijaya, A. 2012. Pendidikan Matematika Realistik suatu Alternatif Pendekatan Pembelajaran Matematika. Yogyakarta: Graha Ilmu.

Wina, Sanjaya. 2010. Perencanaan dan Desain Sistem Pembelajaran. Jakarta: Kencana Prenanda Media Group. 